\title{
ANALISIS KERJASAMA INDONESIA-ARAB SAUDI DALAM PENANGGULANGAN KEJAHATAN TERORISME
}

\author{
Ahmad Zainal Mustofa \\ Program Studi Interdisciplinary Islamic Studies \\ Pascasarjana UIN Sunan Kalijaga Yogyakarta \\ Email: m.ahmadzainal@gmail.com
}

\begin{abstract}
This article describes the diplomatic relations between Indonesia and Saudi Arabia in the security sector. The diplomacy in the security sector is in the form of a bilateral agreement between the two countries in tackling terrorism. This is because terrorism is a global crime that has become the world's attention. The method used in this research is descriptive analytical method. Then the theory used is the concept of national interest. This research was conducted to answer several problems, namely what is the foundation of Indonesia's foreign policy? Then how is the diplomacy between Indonesia and Saudi Arabia in tackling transnational crimes in the form of terrorism? The results of this research are that in implementing foreign policy, Indonesia has three bases as a reference. The foundation is an ideal basis, a constitutional basis and an operational basis. In the security sector, Indonesia and Saudi Arabia have collaborated in the handling of transnational crime, namely terrorism. With the agreement established between the two countries, it is hoped that both Indonesia and Saudi Arabia can carry out efforts to prevent and fight against terrorism effectively and efficiently.
\end{abstract}

Keywords: Indonesia, Saudi Arabia, Security, Terrorism.

\begin{abstract}
ABSTRAK
Artikel ini menjelaskan tentang hubungan diplomatik antara Indonesia dan Arab Saudi dalam bidang keamanan. Diplomasi dalam bidang keamanan ini ditandain dengan adanya kesepakatan antara dua negara dalam menanggulangi kejahatan terorisme. Hal ini dikarenakan terorisme merupakan kejahatan internasional yang menjadi atensi dunia global. Dalam penelitian ini, metode yang digunakan adalah desktiptif analitis. Adapun teori yang digunakan adalah konsep kepentingan nasional. Penelitian ini dilakukan untuk menjawab pertanyaan tentang apa yang menjadi landasan kebijakan politik luar negeri Indonesia? kemudian bagaimana diplomasi antara Indonesia dam Arab Saaudi dalam mencegah kejahatan internasional dalam bidang terorisme? Penelitian ini menyimpulkan bahwa dalam mengimplementasikan kebijakan luar negeri, Indonesia memiliki tiga landasan sebagai acuan. Landasan kebijakan luar negeri Indonesia yaitu landasan ideal, konstitusional dan operasional. Dalam bidang keamanan, Indonesia dan Arab Saudi bekerjasama untuk menanggulangi kejahatan transnasional, khususnya terorisme dengan adanya kesepakatan yang terjalin oleh kedua negara tersebut, diharapkan baik Indonesia dan Arab Saudi bisa melakukan upaya pencegahan dan perlawanan terhadap terorisme secara efektif dan efisien.
\end{abstract}

Kata Kunci: Indonesia, Saudi Arabia, Keamanan, Terorisme. 


\section{PENDAHULUAN}

Perhatian terhadap kejahatan transnasional mulai muncul pada tahun 1990an ketika aktivitas kriminal mulai melewati batas negara dengan cakupan yang cukup signifikan. Perserikatan Bangsa Bangsa (PBB) mengidentifikasikan beberapa kategori kejahatan transnasional yang diketahui memiliki dampak langsung maupun tidak langsung terhadap dua negara atau lebih. Daftar yang dibuat oleh PBB ini memiliki cakupan yang cukup luas dan menyertakan kasus pencucian uang, tindak terorisme dan berbagai kategori kasus lainnya. Daftar yang dikeluarkan oleh PBB memiliki gambaran yang jelas karena menunjukkan fokus perhatian tentang kejahatan yang terpusat pada aktivitas kejahatan terorganisasi dan bukan kejahatan tradisional ataupun kejahatan politik (Albanese, 2016).

Kunjungan kenegaraan Raja Salman bin Abdul Aziz pada tanggal 1-3 Maret 2017 ke Indonesia mengisyaratkan hubungan kedua negara yang berjalan baik. Secara khusus, pemerintah Indonesia dan Arab Saudi melaksanakan rapat terbatas bersama Kepala Badan Nasional Penanggulangan Terorisme (BNPT), Suhardi Alius. Hal ini erat kaitannya dengan penanggulangan terorisme dan radikalisme yang sering terjadi di dunia (Humas, n.d.).

Menyadari bahwa kejahatan lintas negara merupakan bentuk ancaman serius bagi keamanan negara, pemerintah Indonesia menjadikan kunjungan Raja Salman bin Abdul Aziz ke Indonesia pada tahun 2017 lalu sebagai momentum untuk membangun kerja sama di bidang keamanan. Karena jaringan kejahatan lintas negara ini tidak bisa diatasi sendiri, melainkan perlu adanya kerjasama internasional dengan berbagai negara. Dalam konteks perkembangan regional dan internasional yang semakin dinamis, pemerintah Indonesia dituntut untuk menata kembali kebijakan luar negeri dan diplomasinya, serta menentukan prioritas dalam konteks hubungan luar negerinya (Elisabeth, 2016).

Bidang keamanan menjadi hangat diperbincangkan seiring dengan perkembangan teknologi dan lobi diplomasi Indonesia terhadap Arab Saudi yang kemudian menarik minat Arab Saudi untuk berkooperasi dengan Indonesia. Namun berkaitan dengan aspek keamanan global, apa yang menjadi landasan politik luar negeri Indonesia? Kemudian bagaimana diplomasi Indonesia-Arab Saudi dalam penanggulangan kejahatan transnasional dalam bentuk 
terorisme? Penelitian ini akan mencoba mengulas sekilas tentang kejahatan transnasional. Kemudian kerjasama di bidang keamanan dalam rangka penanggulangan aspek terorisme. Lalu kepentingan nasional Indonesia dalam melaksanakan kerjasama dengan kerajaan Arab Saudi.

\section{KERANGKA TEORITIS}

\section{National Interest Concept}

Adapun teori yang digunakan oleh peneliti adalah national interest concept. Konsep kepentingan nasional telah menjadi fokus sentral yang populer dalam studi Hubungan Internasional. Kepentingan nasional merupakan perangkat eksplanatori kunci dalam memahami hubungan internasional, khususnya dalam analisis tentang politik luar negeri dan diplomasi suatu negara yang tidak menyinggung tentang faktor kepentingan nasional tersebut. Dalam pandangan Theodore Couloumbis dan James Wolfe, kepentingan nasional masih menjadi konsep yang sangat penting dalam setiap upaya mendeskripsikan, menjelaskan, memprediksikan atau membuat preskripsi tentang perilaku internasional. Menurut Scott Burchill, kepentingan nasional merupakan motivasi dari suatu negara dalam menjalankan kebijakan eksternalnya, khususnya kebijakan luar negeri (Bakry, 2017).

Kepentingan nasional pada dasarnya adalah rangkuman aspirasi suatu bangsa di bidang politik, ekonomi dan militer. Berdasarkan sifatnya, kepentingan nasional dapat diklasifikasikan ke dalam dua bentuk besar, yaitu kepentingan nasional yang kekal dan kepentingan nasional yang dapat berubah-ubah sesuai dengan perkembangan waktu. Dari dua klasifikasi itu, biasanya kepentingan nasional akan dibagi-bagi dalam strata yang mencakup keduanya (Muradi, 2013). Donald E. Nuechterlein, mempertegas konsep kepentingan nasional suatu negara berdasarkan pada empat aspek, yaitu: Kepentingan Pertahanan, Kepentingan Ekonomi, Kepentingan Tatanan Dunia dan Kepentingan Ideologis (Nuechterlein, 1976).

Berdasarkan penjelasan tersebut, kepentingan nasional merupakan sebuah model politik yang bertujuan untuk memberikan keuntungan bagi negaranya. Kepentingan nasional ini bisa dengan cara diplomasi antar negara untuk memperkuat elemen-elemen pertahanan dan keamanan, ekonomi, ideologi dan politiknya. Sebagaimana dalam pembahasan penelitian ini 
akan menguraikan tentang diplomasi antara Indonesia dan Arab Saudi dalam menanggulangi kejahatan terorisme beserta kepentingan nasionalnya.

\section{METODE PENELITIAN}

Metode penelitian adalah cara-cara yang digunakan dalam penelitian yang meliputi kegiatan berfikir dan dan berbuat untuk mencapai tujuan penelitian tertentu (Kartini, 1996). Penelitian ini adalah penelitian yang berjenis kepustakaan (library research), dengan mengumpulkan berbagai macam informasi yang berasal dari buku-buku, majalah, artikel, dan berbagai sumber yang berkaitan dengan penelitian ini (Mardalis, 2008). Metode penelitian yang digunakan adalah metode deskriptif analitis yaitu sebuah metode pengumpulan data dengan menghimpun data yang relevan dengan pembahasan terlebih dahulu, baru kemudian dianalisis. Adapun teknik pengumpulan data yang dilakukan dalam penelitian ini adalah teknik dokumentasi. Teknik dokumentasi adalah sebuah teknik pengumpulan data yang bersumber dari dokumen, seperti buku, jurnal, surat kabar, majalah, maupun laporan penelitian yang kemudian dijadikan sebagai data penelitian (Moehnilabib \& dkk, 1997). Semua sumber tersebut difilterisasi oleh penulis agar bisa menghasilkan data yang akurat yang bisa mengakomodasi bentuk-bentuk kebijakan yang terjadi secara substansial dan esensial.

\section{PEMBAHASAN}

\section{Politik Luar Negeri Indonesia}

Secara umum politik luar negeri sering dipahami sebagai kelanjutan dari politik dalam negeri. Oleh karena itu, kebijakan luar negeri suatu negara tidak berada di dalam ruang yang vakum, melainkan interaksi yang dinamis dalam masyarakat internasional serta interaksi antara persoalan-persoalan lokal dan global (Wuryandari, 2011). Istilah politik luar negeri telah didefinisikan dengan berbagai cara oleh para sarjana. Namun mereka yakin bahwa ini berkaitan dengan perilaku dari suatu negara menuju negara bagian lain. Hermann misalnya, ia mendefinisikan kebijakan asing sebagai "tindakan sengaja yang dihasilkan dari politik 
keputusan tingkat individu atau kelompok individu yang produk keputusannya dapat diamati dari keputusan tingkat politik." Di sini terlihat bahwa Hermann mendefinisikan kebijakan luar negeri sebagai perilaku negara (AS, 2018).

Pada aspek hubungan internasional, Indonesia tentu saja memiliki kebijakan luar negeri dalam berpolitik dan berdiplomasi di dunia internasional. Adapun prinsip kebijakan politik luar negeri Indonesia adalah bebas-aktif. Pada pelaksanaannya, Indonesia menjalankan politik luar negeri bebas-aktif dengan bertumpu pada ideologi Pancasila dan Undang-Undang Dasar 1945 (Putera, n.d.).

Dengan menganut prinsip politik luar negeri bebas-aktif sebagai landasan kebijakan dan kepentingan nasionalnya, Indonesia menjadi negara yang memiliki hak penuh dalam menentukan kebijakan tanpa ada intervensi dari pihak lain. Prinsip bebas dapat diartikan bahwa Indonesia tidak memihak kepada siapapun atau ikut berpartisipasi terhadap kekuatan-kekuatan yang tidak sesuai dengan prinsip dan nilai luhur bangsa. Sementara itu, prinsip aktif artinya Indonesia tidak hanya diam di tempat, namun Indonesia aktif menjalin hubungan internasional untuk mewujudkan ketertiban dunia. Dengan berpedoman pada prinsip politik bebas-aktif, bangsa Indonesia dapat menentukan arah, sikap dan bisa memposisikan diri sebagai negara kesatuan yang merdeka dan berdaulat sebagaimana amanah konstitusi UUD 1945 (Welianto, n.d.).

Dalam berpolitik dan menentukan arah kebijakan hubungan antar negara, Indonesia memiliki tiga landasan untuk merumuskan kebijakan. Pertama, landasan idiil yang menjadi pedoman dalam hubungan internasional. Pancasila adalah dasar negara Indonesia dan juga sebagai landasan idiil dalam berpolitik luar negeri (Sihbudi, 1997). Kedua, landasan konstitusional politik luar negeri Indonesia adalah Undang-Undang Dasar (UUD) 1945. Di dalam UUD 1945 juga menyatakan bahwa Indonesia turut berjuang menentukan arah perkembangan regional dan internasional dalam menjaga ketertiban dunia berdasarkan kemerdekaan, perdamaian abadi dan keadilan sosial (Elisabeth, 2016). Ketiga, landasan operasional merupakan landasan politik luar negeri Indonesia selain landasan idiil dan landasan konstitusional. Landasan operasional sendiri memiliki undang-undang yang mengatur untuk terselenggaranya hubungan internasional (Mila \& dkk., 2020). 


\section{Sekilas Tentang Kejahatan Transnasional}

Kejahatan transnaional terorganisir merupakan salah satu bentuk dan efek dari globalisasi yang menjadi ancaman bagi keamanan negara (state security) sekaligus pada penduduk yang hidup dalam negara (human security). Terhadap negara, berbagai bentuk kejahatan transnasional mengecilkan peran negara dalam mengontrol batas teritorial dan kedaulatannya. Kemudian pada saat yang sama, kejahatan tersebut memberikan ancaman besar pada kondisi keamanan warga negara dalam berbagai aspek. Efek globalisasi ini juga menandakan bahwa tidak ada negara yang bisa menyatakan diri sepenuhnya aman dari ancaman kejahatan (Burhanuddin, 2017).

Dalam memahami peran penting kejahatan terorganisasi dalam kejahatan transnasional secara umum, Perserikatan Bangsa-Bangsa (PBB) membuat sebuah mekanisme multilateral melalui sebuah perjanjian internasional yang disebut United Nations Convention on Transnational Organized Crime (UNTOC). Konvensi Kejahatan Terorganisasi Transnasional dibentuk pada bulan Desember tahun 2000 sekaligus menjadi panduan dasar bagi negara-negara dalam upaya penanggulangan kejahatan lintas negara. Konvensi tersebut membuat model hukum, kebijakan, teknik penegakan dan strategi pencegahan untuk melawan kelompok kriminal transnasional. Tidak hanya itu, kejahatan pencucian uang, perlindungan saksi dan perlindungan terhadap para tokoh kejahatan terorganisasi juga menjadi atensi yang penting untuk ditegakkan. Konvensi ini harus ditandatangani oleh 40 negara agar dapat diberlakukan, akhirnya pada tahun 2003 konvensi ini berhasil memenuhi syarat minimal dan berlaku dalam skala internasional (Albanese, 2016).

Secara tradisional, kejahatan transnasional diartikan sebagai aktivitas kriminal yang terjadi dan melanggar hukum dua negara atau lebih. Apabila bicara tentang kejahatan transnasional, umumnya negara ataupun organisasi internasional akan merujuk pada kelompok aktivitas ilegal dari kategori ini berbagai macam. Sebagai contoh adalah organisasi penipuan internasional menggunakan surat elektronik dan media sosial yang berbasis di Nigeria dan organisasi penyalur penyelundupan manusia dari Albania (Burhanuddin, 2017). 


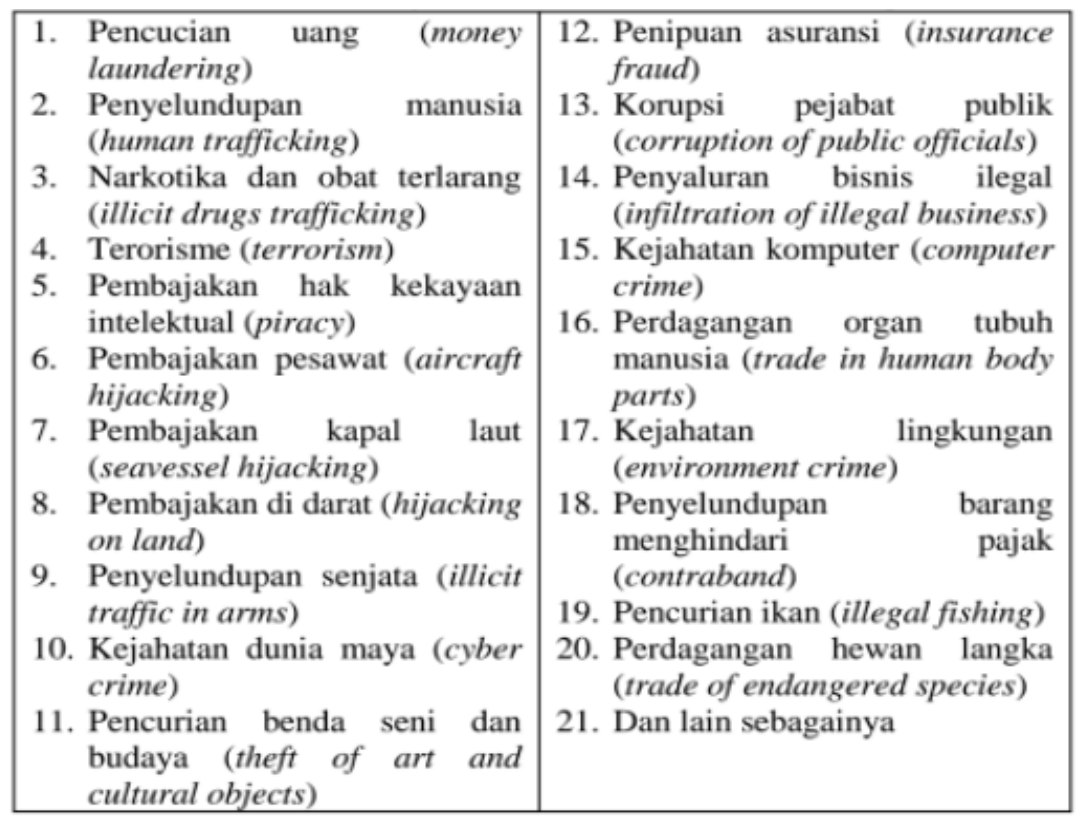

\section{Gambar 1. Tabel Ruang Lingkup Kejahatan Transnasional}

Kejahatan lintas negara merupakan bentuk kejahatan yang menjadi ancaman serius terhadap keamanan dan kemakmuran global mengingat sifatnya yang melibatkan berbagai negara. Dari sisi Indonesia, kejahatan lintas negara perlu diberikan perhatian khusus mengingat letak Indonesia yang sangat strategis sehingga rentan terhadap berbagai bentuk kejahatan lintas negara. Untuk itu, Kementerian Luar Negeri sebagai ujung tombak Pemerintah Indonesia dalam kerjasama internasional senantiasa mengintensifkan kerja sama internasional dalam mengatasi kejahatan-kejahatan lintas negara guna melindungi kepentingan dan kedaulatan nasional Indonesia. Dalam perkembangannya, Indonesia menaruh perhatian khusus terhadap kejahatan lintas negara baru dan berkembang, antara lain perdagangan orang dan penyelundupan manusia, korupsi dan pencucian uang, kejahatan kehutanan dan satwa liar, kejahatan perikanan, perdagangan ilegal benda-benda cagar budaya, serta kejahatan narkotika dan obat-obatan (narkoba) dan prekursornya (kemlu.go.id, n.d.). 


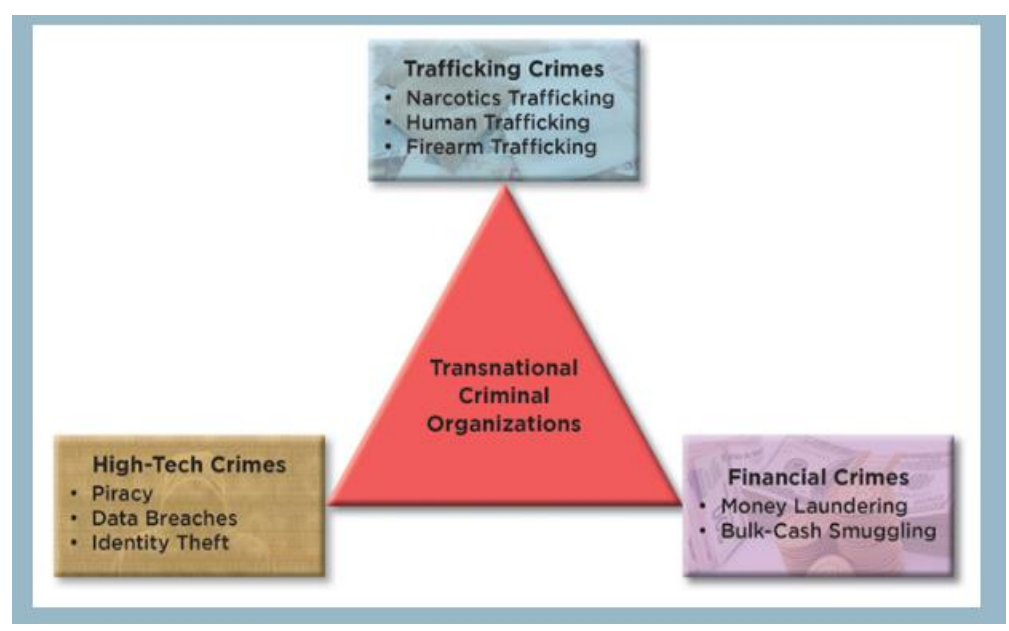

Gambar 2. Bagan Organisasi Kriminal Transnasional

Upaya untuk menjaga dan mempertahankan kedaulatan Negara Kesatuan Republik Indonesia juga merupakan salah satu aspek dalam hubungan luar negeri. Karenanya warga masyarakat turut menjaga ketertiban dan kedamaian dalam negeri maupun luar negeri. Oleh karena itu, landasan konstitusional menjadi pedoman Indonesia untuk meningkatkan ketertiban, perdamaian dan keadilan baik di dalam maupun luar negeri dalam bentuk kerjasama internasional. Dalam melaksanakan program kerjasama baik bilateral maupun multilateral, Indonesia harus bisa melakukan filterisasi hubungan dengan negara yang bisa memberikan keuntungan bagi bagi pemerintah dan masyarakat. Hal tersebut bisa meningkatkan daya saing bagi Indonesia di mata dunia internasional, sehingga Indonesia memiliki daya tarik bagi negaranegara lain untuk turut menjajaki kerjasama dalam berbagai bidang.

\section{Kerjasama Indonesia-Arab Saudi dalam Penanggulangan Terorisme}

Kejahatan terorisme merupakan perilaku negatif yang dapat mengancam kedaulatan setiap negara. Karena urgensi tersebut maka wajib bagi negara melindungi masyarakatnya dari aksi terror dan aktivitas yang mendukung kegiatan terorisme. Sebagaimana yang dikatakan oleh Romli Atmasasmita -Guru Besar Hukum Pidana Internasional Universitas Padjadjaranterorisme tergolong dalam kejahatan luar biasa (extra-ordinary crimes), baik dalam struktur organisasi, motif, modus operandi hingga pendanaannya. Kejahatan yang dilakukan oleh kelompok terorisme internasional serta domestik sering dibalut dengan motif agama. Mereka memperjuangkan ideologi dan menilai adanya kesenjangan sosial yang terjadi di masyarakat. Menurut Hamid Awaludin yang merupakan mantan menteri Hukum dan HAM RI, menyatakan 
bahwa kegiatan terorisme dapat dikategorikan sebagai tindak kejahatan internasional, karena melanggar limitasi kepentingan masyarakat internasional yaitu terciptanya keamanan, ketertiban dan perdamaian dunia (Safrudin, 2013).

Indonesia senantiasa berkomitmen dalam upaya penanggulangan terorisme, termasuk diantaranya upaya penanggulangan terorisme di bawah kerangka PBB. Dalam kaitan ini, Indonesia berperan aktif dalam melakukan kerja sama dengan United Nations Counter Terrorism Implementation Task Force (UNCTITF), Terrorism Prevention Branch-United Nation Office for Drugs and Crime (TPB-UNODC), dan United Nations Counter-Terrorism Executive Directorate (UNCTED). Lebih lanjut, Indonesia melakukan upaya untuk mengimplementasikan empat pilar United Nations Global Counter-Terrorism Strategy (UNGCTS) (kemlu.go.id, Indonesia dan Upaya Penanggulangan Terorisme, n.d.).

Setidaknya ada dua hal yang menjadi karakteristik dari terorisme, yaitu: pertama, karakteristik organisasi dan kedua, karakteristik sumber daya. Dunia mulai menyadari bahwa untuk memerangi terorisme tidak cukup hanya mengandalkan kekerasan, karena pada dasarnya perang akan dibalas dengan perang sehingga tidak akan menyelesaikan permasalahan yang terjadi. Pada kasus terbunuhnya Osama bin Laden dan Ayman Zawahiri, AS menganggap mereka sudah menghilangkan aktor dari terorisme. Namun pada kenyatannya, terorisme bukannya mati melainkan tumbuh subur karena terbunuhnya para aktor tersebut dan menuntut balas dendam (K., 2005).

Di berbagai negara telah terjadi kejahatan terorisme, baik di negara maju maupun negara-negara sedang berkembang. Aksi-aksi teror yang dilakukan telah memakan korban tanpa pandang bulu, yang menyebabkan Perserikatan Bangsa Bangsa dalam kongresnya di Wina Austria tahun 2000 mengangkat tema "The Prevention of Crime and The Treatment of Offenders," antara lain menyebutkan terorisme sebagai suatu perkembangan perbuatan dengan kekerasan yang perlu mendapat perhatian (Junaid, 2013).

Menurut Muladi, terorisme merupakan kejahatan luar biasa (extraordinary crime) yang membutuhkan pula penanganan dengan mendayagunakan cara-cara luar biasa (extraordinary measure) karena berbagai hal berikut: 
a. Terorisme merupakan perbuatan yang menciptakan bahaya terbesar (the greatest danger) terhadap hak asasi manusia. Dalam hal ini hak asasi manusia untuk hidup (the right to life) dan hak asasi untuk bebas dari rasa takut.

b. Target terorisme bersifat random atau indiscriminate yang cenderung mengorbankan orangorang tidak bersalah.

c. Kemungkinan digunakannya senjata-senjata pemusnah massal dengan memanfaatkan teknologi modern.

d. Kecenderungan terjadinya sinergi negatif antar organisasi terorisme nasional dengan organisasi internasional.

e. Kemungkinan kerjasama antara organisasi teroris dengan kejahatan yang terorganisasi baik yang bersifat nasional maupun internasional.

f. Dapat membahayakan perdamaian dan keamanan internasional.

Kompleksitas permasalahan dalam kejahatan transnasional ini bisa membahayakan keamanan negara apabila pemerintah tidak segera membangun relasi kerjasama antar negara dengan berbagai negara. Tentu saja kerjasama dengan Arab Saudi di bidang keamanan ini bisa membantu Indonesia untuk melakukan pencegahan dini salah satunya kasus terorisme. Seperti kita ketahui bersama bahwa terorisme identik dengan Islam dan Timur Tengah. Sebagai negara besar di Timur Tengah, Arab Saudi memiliki banyak data mengenai kelompok terorisme beserta jaringannya. Kedua negara tersebut bisa bertukar pikiran, data dan strategi untuk memerangi terorisme secara efektif dan efisien.

Pada masa pemerintahan presiden Joko Widodo, hubungan diplomasi antara Indonesia dan Arab Saudi telah menghasilkan 11 Memorandum of Understanding (MoU) sebagai bentuk peningkatan hubungan bilateral kedua negara, berikut daftar kesepakatan yang terjalin antar kedua negara (Damarjati, n.d.):

1. Deklarasi pemerintah perihal peningkatan pimpinan sidang komisi bersama ditandatangani Menlu Retno LP Marsudi dan Menlu Saudi.

2. Nota kesepahaman mengenai kontribusi pendanaan Saudi dengan pembiayaan proyek pembangunan antara Saudi Fund Development dan Pemerintah Republik Indonesia ditandatangani Menkeu Sri Mulyani dan Wakil Direktur Saudi Fund. 
3. Nota kesepahaman kerja sama kebudayaan antara Kementerian Pendidikan dan Kebudayaan Republik Indonesia dan Kementerian Kebudayaan dan Informasi Kerajaan Arab Saudi ditandatangani Mendikbud Muhadjir Effendy dan pihak Saudi.

4. Program kerjasama antara Kementerian Koperasi dan Usaha Kecil dan Menengah Republik Indonesia dan Otoritas Usaha Kecil dan Menengah Kerajaan Arab Saudi mengenai pengembangan usaha kecil dan menengah ditandatangani Menkop Puspayoga dan pihak Saudi.

5. Nota kesepahamaan antara Kementerian Kesehatan RI dan Kementerian Kesehatan Arab Saudi di bidang kerja sama kesehatan ditandatangani Menkes Nila Moeloek dan pihak Saudi.

6. Nota kesepahaman otoritas aeronautika Republik Indonesia dan otoritas Arab Saudi ditandatangani Menhub Budi Karya dan pihak Saudi.

7. Program kerja sama antara Kementerian Riset Teknologi dan Pendidikan Tinggi dan Kementerian Pendidikan Arab Saudi dalam bidang kerja sama saintifik dan pendidikan tinggi ditandatangani Menristek Dikti Muhammad Nasir dan Menteri Pendidikan Arab Saudi.

8. Nota kesepahaman antara Kementerian Agama RI dan Kementerian Urusan Islam Dakwah dan Bimbingan Kerajaan Arab Saudi di bidang urusan Islam.

9. Nota kesepahaman pemerintah Indonesia dan Arab Saudi di bidang kerja sama kelautan dan perikanan ditandatangani Menteri Kelautan Susi Pudjiastuti dan pihak Arab Saudi.

10. Program kerja sama perdagangan antara Kementerian Perdagangan RI dengan Kementerian Perdagangan dan Investasi Kerajaan Saudi ditandatangani oleh Mendag Enggartiasto Lukito dan Kemendag Saudi.

11. Kerja sama di bidang penanganan kejahatan antar negara (transnational crime) antara Indonesia dan Arab Saudi yang ditandatangani oleh Jenderal Tito Karnavian dan kepala kepolisian Arab Saudi.

Diantara 11 MoU yang telah disepakati oleh pihak Pemerintah RI- Arab Saudi, salah satunya adalah kerja sama di bidang penanganan kejahatan antar negara (transnational crime) antara Indonesia dan Arab Saudi yang ditandatangani oleh Kapolri Jenderal Tito Karnavian dan Kepala Kepolisian Arab Saudi. Memang tidak disebutkan secara rinci bentuk dari kerjasama 
penanganan kejahatan transnasional. Komisi I setujui RUU Kerja Sama Pertahanan Indonesia dengan Belanda dan Arab Saudi, namun Duta Besar Arab Saudi untuk Indonesia, Osama bin Mohammed Abdullah Al Shuaibi mengungkapkan bahwa salah satu agenda utama Raja Salman adalah kerjasama untuk memerangi aksi terorisme. Dengan demikian kedua negara bisa bertukar data, pengalaman untuk melumpuhkan jaringan teroris di dalam maupun luar negeri (Asmara, n.d.).

Terjadinya kesepakatan antara Indonesia dan Arab Saudi dalam bidang keamanan menandakan adanya faktor national interest yang mendorong kedua negara untuk melakukan MoU. Pada satu sisi, Indonesia berusaha mencegah dan memerangi adanya aksi terorisme yang dapat membahayakan masyarakat. Di sisi lain, Arab Saudi juga berupaya memerangi terorisme yang dapat membahayakan negaranya. Tidak hanya itu, pelaku kejahatan terorisme seringkali diidentikkan dengan ajaran Islam. Bahkan dunia Barat -khususnya Amerika Serikat- menyebut beberapa negara di Timur Tengah sebagai sarang teroris. Hal ini memiliki korelasi bahwa ratarata warga negara Timur Tengah itu beragama Islam, terlebih secara historis Timur Tengah juga erat kaitannya dengan penyebaran agama Islam pertama kali di dunia. Indonesia dan Arab Saudi tentu tidak ingin Islam selalu diidentikkan dengan perilaku kejahatan terorisme dan radikalisme. Oleh karena itu, MoU ini diharapkan bisa mencegah aksi terorisme yang tidak hanya berbahaya bagi dunia, namun juga bagi agama.

\section{Kepentingan Ekonomi dan Perkembangan Teknologi}

Tingkat perkembangan ekonomi suatu negara juga berpengaruh pada kebijakan luar negeri negara itu. Banyak industrialis negara maju memainkan peran dominan dalam politik dunia, dan merumuskan kebijakan luar negeri mereka untuk mempertahankan keunggulannya. Negara-negara tersebut seperti Amerika Serikat, Rusia, Jerman, dan Prancis. Mereka memiliki sumber daya yang besar untuk membangun kemampuan militer di satu sisi, dan menyebarkan keuntungan moneter di negara lain dalam bentuk bantuan dan pinjaman, dengan tujuan "mencari sekutu". Di sisi lain, negara-negara kecil seperti Gambia yang terbatas dalam mengejar kebijakan luar negeri tidak dihitung karena ekonomi mereka tidak mencukupi kekuasaan. Oleh karena itu, dapat dilihat bahwa berkembang dan negara-negara yang belum berkembang tetap bergantung pada kemajuan negara-negara industry, sehingga mereka dapat memperoleh pinjaman pembangunan, impor teknologi, penyediaan perawatan kesehatan, akses kependidikan 
tinggi, dan bahkan biji-bijian makanan untuk memenuhi kebutuhan mereka. Jadi dengan kata lain mereka dituntut untuk menyesuaikan kebijakan luar negerinya terhadap perekonomian tersebut (Ahmed, 2020).

Kunjungan Raja Salman ke Indonesia yang ditandai dengan penandatanganan $11 \mathrm{MoU}$ menunjukkan bahwa dinamika perekonomian dunia sudah semakin bergeser dari Barat ke Timur, yaitu dari yang berbasis modal ke sumber daya manusia. Penandatanganan $11 \mathrm{MoU}$ ini merupakan komitmen jangka panjang kedua negara untuk meningkatkan kerja sama ekonomi, politik, dan kebudayaan. Indonesia yang memiliki pertumbuhan ekonomi 5 persen per tahun, penduduk lebih dari 200 juta orang, kondisi politik yang stabil, demokratis dan terbuka, menjadi magnet bagi Arab Saudi. Di sisi lain, dalam kancah politik regional, Indonesia adalah pintu gerbang ASEAN yang dihuni oleh lebih dari 625 juta orang serta memiliki pertumbuhan ratarata di atas 5 persen (Wangke, 2017).

Upaya memperkuat hubungan kedua negara ke depan perlu dilakukan terutama dengan membangun komitmen bersama untuk memajukan hubungan bilateral. Indonesia sangat perlu memanfaatkan kondisi internal Arab Saudi yang saat ini sedang mengalami masa transisi ekonomi. Dalam visi Saudi 2030, negara itu akan mengurangi ketergantungan terhadap minyak tanpa menimbulkan dampak besar bagi perubahan masyarakat Arab Saudi dalam era modern, tidak terkecuali perubahan sosial, ekonomi, dan politik. Perjanjian kerjasama RI-Arab Saudi ini tentu saja diharapkan bisa membawa dampak positif bagi kedua negara. Selain itu, implementasi dari hubungan bilateral ini memberikan hasil yang signifikan bagi pertahanan kedua negara ke arah yang lebih baik dan menguntungkan kedua belah pihak.

Selain itu, Indonesia juga menaruh perhatian khusus pada aspek kekuatan nasional sebagai daya tarik global supaya bisa mencukupi kepentingan nasionalnya. Indonesia juga mempertimbangkan beberapa faktor strategis untuk dijadikan sebagai kekuatan nasional, antara lain: kekuatan militer, letak kondisi geografis, politik, ekonomi dan sumber daya negara, jumlah dan kualitas penduduk, serta ideologi negara. Kekuatan nasional yang dimiliki Indonesia yang dijadikan daya tarik global tersebut nantinya akan membantu keberlangsungan proses hubungan internasional. Hal tersebut dikarenakan aspek kekuatan nasional akan menjadi acuan sukses atau tidaknya suatu interaksi negara yang tengah berlangsung. Setiap aktor tentu saja memiliki 
kekuatan yang berbeda. Perbedaan tersebut tidak bisa menguntungkan semua aktor karena semakin besar kekuatan aktor tersebut maka semakin mudah aktor itu memaksimalkan kekuatannya untuk berkuasa dalam lingkup hubungan internasional (Putera, n.d.).

Indonesia tentu saja tidak ingin melewatkan kesempatan emas untuk mempererat hubungan kedua negara. Kehangatan hubungan diplomatik bilateral ini dinamai dengan diplomasi Saudinesia. Secara umum, ketertarikan Indonesia terhadap Arab Saudi tidak hanya seputar pertahanan dan keamanan saja, tetapi Indonesia juga menginginkan kerjasama seperti penyelenggaraan ibadah Haji dan Umroh serta di bidang ketenagakerjaan. Namun, aspek pertahanan dan keamanan juga tidak luput dari perhatian Indonesia.

Dengan adanya jalinan kerjasama di bidang keamanan, Indonesia bisa menawarkan jual beli alutsista buatan dalam negeri kepada Arab Saudi sehingga bisa mendatangkan keuntungan bagi Indonesia. Selain itu, Indonesia bisa memanfaatkan program kerjasama bilateral untuk mematangkan unsur-unsur pertahanan negara seperti pertukaran personil angkatan bersenjata Indonesia dengan Arab Saudi untuk pendidikan bersama di bidang militer. Kemudian Indonesia bisa memanfaatkan Arab Saudi yang merupakan negara kawasan Timur Tengah untuk bertukar informasi terkait keamanan, khususnya masalah teorisme. Dengan demikian, Indonesia dapat menambah pengetahuan tentang jaringan terorisme di Timur Tengah untuk kemudian melakukan tindakan pencegahan terhadap terorisme dalam negeri dan luar negeri sebagai bagian dari amanah UUD 1945, menciptakan perdamaian dunia.

\section{KESIMPULAN}

Dalam melakukan suatu kebijakan politik, diplomasi dan hubungan internasional, Indonesia memiliki tiga landasan sebagai pedoman, yaitu: landasan idiil, landasan konstitusional dan landasan operasional. Sehingga dalam sebuah hubungan internasional, Indonesia tetap bisa melakukan kerjasama bilateral tetapi tetap berpijak sesuai pedoman negara. Kerjasama Indonesia-Arab Saudi menghasilkan kesepakatan yang salah satunya di bidang pertahanan dan keamanan. Dalam bidang pertahanan, Indonesia dan Arab Saudi meyepakati tentang program pendidikan dan latihan, pertukaran personel, pengembangan industri 
kesenjataan dan bantuan kemanusiaan. Sedangkan dalam bidang keamanan, Indonesia-Arab Saudi berkomitmen untuk melawan kejahatan antar negara. Salah satu poin utama dari kerjasama kejahatan antar negara adalah penanggulangan terorisme. Dengan adanya kesepakatan yang terjalin antara kedua negara tersebut diharapkan baik Indonesia maupun Arab Saudi bisa melakukan upaya pencegahan dan perlawanan terhadap terorisme secara efektif dan efisien.

\section{DAFTAR PUSTAKA}

Ahmed, J. (2020). The Theoretical Significance Of Foreign Policy In International RelationsAn Analyses. Journal of Critical Reviews, 7(2), 707-792.

Albanese, J. S. (2016). Kejahatan Terorganisasi (Organized Crime): Akar dan Perkembangannya. Jakarta: Penamedia Group.

AS, B. (2018). The Study of Foreign Policy in International Relations. Journal of Political Sciences \& Public Affairs, 6(4), 1-9.

Asmara, T. (n.d.). Indonesia dan Arab Saudi Kerjasama Melawan Terorisme. Retrieved March 14, 2019, from https://www.benarnews.org/indonesian/berita/indonesia-saudiantiterorisme-03012017164154.html

Bakry, U. S. (2017). Dasar-Dasar Hubungan Internasional. Depok: KENCANA.

Burhanuddin, A. (2017). Studi Keamanan dan Isu-Isu Strategis Global. Lembaga Kajian dan Pengembangan Pendidikan Universitas Hasanudin.

Damarjati, D. (n.d.). Ini 11 MoU antara Indonesia dan Arab Saudi. Retrieved August 28, 2020, from https://news.detik.com/berita/d-3435465/ini-11-mou-antara-indonesia-dan-arabsaudi.

Elisabeth, A. (2016). Grand Design: Kebijakan Luar Negeri Indonesia (2015-2025). Jakarta: Pustaka Obor Indonesia.

Humas. (n.d.). Berkunjung ke Indonesia, Raja Saudi Salman Al Saud Bawa 1500 Rombongan, 25 Pangeran. Retrieved from https://setkab.go.id/berkunjung-ke-indonesia-raja-saudisalman-al-saud-bawa-1500-rombongan-25-pangeran/

Junaid, H. (2013). Pergerakan Kelompok Terorisme dalam Perspektif Barat dan Islam. Sulesana, Jurnal Wawasan Keislaman, 8(2), 109-125.

K., B. P. (2005). The War for Muslim Minds: Islam and the West. Jurnal International Relations of the Asia-Pacific, 6(1), 110-130. 
Kartini, K. (1996). Pengantar Metodologi Riset Nasional. Bandung: Mondari Maju.

kemlu.go.id. (n.d.). Indonesia dan Upaya Penanggulangan Terorisme. Retrieved Juny 4, 2020, from https://kemlu.go.id/portal/id/read/95/halaman_list_lainnya/indonesia-dan-upayapenanggulangan-terorisme

kemlu.go.id. (n.d.). Kejahatan Lintas Negara. Retrieved March 14, 2019, from https://kemlu.go.id/portal/id/read/89/halaman_list_lainnya/kejahatan-lintas-negara

Mardalis. (2008). Metode Penelitian: Suatu Pendekatan Proposal. Jakarta: Bumi Aksara.

Mila, N., \& dkk. (2020). Sejarah Perkembangan Politik Luar Negeri Indonesia Masa Pasca Reformasi. Jurnal Pendidikan Pancasila Dan Kewarganegaraan, 1(2), 73-100.

Moehnilabib, \& dkk. (1997). Dasar-dasar Metodologi Penelitian. Malang: Lembaga Penelitian IKIP Malang.

Muradi. (2013). Penataan Kebijakan Keamanan Nasional. Bandung: Dian Cipta.

Nuechterlein, D. E. (1976). National interests and foreign policy: A conceptual framework for analysis and decision-making. Brit. J. International Studies 2, 246-266.

Putera, E. W. (n.d.). Esensi Hubungan Internasional dan Kebijakan Politik Luar Negeri Indonesia. Retrieved Juny 4, 2020, from https://setkab.go.id/esensi-hubunganinternasional-dan-kebijakan-politik-luar-negeri-indonesia/

Safrudin, R. (2013). Penanggulangan Terorisme Di Indonesia Melalui Penanganan Pendanaan Terorisme: Studi Kasus Al-Jamaah Al-Islamiyah (JI). Jurnal Pertahanan, 3(1), 113-137.

Sihbudi, R. (1997). Indonesia-Timur Tengah: Masalah dan Prospek. Jakarta: Gema Insani Press.

Wangke, H. (2017). Arti Penting Kunjungan Raja Salman Ke Indonesia. Majalah Info Singkat Hubungan Internasionall/Puslit, 9(5), 5-8.

Welianto, A. (n.d.). Politik Luar Negeri Indonesia. Retrieved Juny 4, 2020, from https://www.kompas.com/skola/read/2020/03/05/200000469/politik-luar-negeriindonesia?page=all.

Wuryandari, G. (2011). Politik Luar Negeri Indonesia: Di Tengah Arus Perubahan Politik Internasional. Yogyakarta: Pustaka Pelajar. 